\title{
AKTIVITAS ANTIHIPERGLIKEMI DAN PENURUN LIPID PEROKSIDASE EKSTRAK ETANOL BUAH PARE (Momordica charantia L.) PADA TIKUS DIABETES MELLITUS YANG DIINDUKSI ALOKSAN
}

\author{
Dahlia andayani ${ }^{1}$, Gunawan Pamudji ${ }^{2}$, Rina Herowati ${ }^{3}$ \\ 1. Fakultas Ilmu Kesehatan Universitas Nahdlatul Wathan Mataram \\ 2,3 Fakultas Farmasi Universitas Setia Budi
}

\begin{abstract}
ABSTRAK
Stres oksidatif menyebabkan terjadinya kerusakan pada berbagai organ dan bertanggung jawab terhadap komplikasi pada DM. Buah pare (Momordica charantia, L) adalah salah satu tanaman yang sering digunakan sebagai obat diabetes di Indonesia. Penelitian ini bertujuan untuk mengevaluasi efek antihiperglikemi dan penurunan peroksidasi lipid ekstrak etanol buah pare pada tikus DM yang diinduksi aloksan dosis $150 \mathrm{mg} / \mathrm{kg}$ BB. Ekstrak etanol buah pare (MCE) diberikan secara oral dosis 100 dan $200 \mathrm{mg} / \mathrm{kg}$ BB selama 30 hari dan dibandingkan dengan glibenklamid.

Hasil penelitian menunjukkan kedua dosis ekstrak etanol buah pare dapat menurunkan kadar glukosa darah signifikan $(\mathrm{p}<0,05)$ dibanding tikus kontrol diabetes dan menurunkan kadar MDA. Dosis tinggi ekstrak etanol buah pare $(200 \mathrm{mg} / \mathrm{kg} \mathrm{BB})$ lebih efektif menurunkan kadar MDA kembali normal dibandingkan dengan glibenklamid. Dosis tinggi ekstrak etanol buah pare juga meningkatkan ukuran diameter sel islet signifikan $(\mathrm{p}<0,05)$ dibanding kontrol diabetes.
\end{abstract}

\section{PENDAHULUAN}

Komplikasi DM berhubungan dengan kerusakan jaringan yang disebabkan oleh kadar glukosa darah yang tinggi (hiperglikemi) (Setiawan \& Suharsono, 2005). Hiperglikemi kronis dapat menginduksi pelepasan radikal bebas yang bertanggung jawab terhadap terjadinya stres oksidatif pada DM. Stres oksidatif ini memicu terjadinya berbagi kerusakan sel (Bhaskar \& Kumar, 2012) sehingga menyebabkan komplikasi seperti neuropati, nefropati, retinopati, dan beberapa kelainan makrovaskuler lainnya (Robertson, 2004).

Dalam keadaan normal radikal bebas yang diproduksi di dalam tubuh akan dinetralisir oleh antioksidan alami yang ada didalam tubuh (Droge W., 2002). Tetapi pada DM memerlukan asupan antioksidan dalam jumlah yang besar karena peningkatan radikal bebas akibat hiperglikemia (Erejuwa, 2010). DM kronis merubah kapasitas antioksidan karena tingginya stres oksidatif (Ravi et al., 2004).

Pengobatan penyakit kelainan metabolik seperti DM dengan obat oral konvensional seringkali terkait masalah efek samping dan mahalnya harga obat, untuk itu diperlukan strategi terapi alternatif lain seperti obat dari bahan alam yang diyakini mempunyai efek samping yang kecil (Moniruzzaman, 2012). Banyak penelitian yang melaporkan efek hipoglikemi tumbuhan obat dan mempunyai aktivitas sebagai antioksidan juga, hal ini sejalan dengan bahaya DM terkait dengan komplikasi yang terjadi karena stres oksidatif (Gomathi et al., 2013; Kanter et al., 2004; Kumar et al., 2013)

Buah pare (Momordica charantia L.) adalah buah dari tumbuhan merambat yang sudah lama dikenal oleh masyarakat, dikonsumsi dan diolah menjadi sayuran. Secara tradisional buah pare yang dimasak digunakan oleh masyarakat sebagai obat penurun gula darah pada DM, kandungan gizi dan vitaminnya bermanfaat untuk kesehatan. Buah dengan rasa pahit ini baik biji maupun daging buahnya juga digunakan sebagai obat batuk, demam, cacingan, diare, diabetes, luka, luka bakar dan penyakit kulit lainnya. Manfaat buah pare sebagai obat diabetes atau obat hipoglikemi sudah banyak dibuktikan melalui penelitian 
ilmiah (Ayoub et al., 2013), aktivitas lain ekstrak buah pare seperti aktivitas antibakteri (Omeregbe et al., 1996; antivirus (Lee-Huang, 1995), sitotoksik (Lee-Huang, 1995), penurun trigliserida (Sennayake et al., 2004), antiinflamasi (Kobori et al., 2008), dan aktivitas antioksidan sebagai penangkal radikal bebas (Wu \& Ng, 2007).

Beberapa senyawa yang memiliki aktivitas hipoglikemi dari buah pare sudah diidentifikasi diantaranya: glikosida steroid (karantin), p-insulin atau v-insulin) yang memiliki aktivitas insulinomimetik dan alkaloid yang terkonsentrasi pada buah dari tanaman (Kumar et al., 2010).

\section{METODE}

Penyiapan bahan. Buah pare diperoleh dari pasar gede kota Surakarta. Pare dicuci bersih, diparut kemudian dikeringkan dengan oven suhu $50^{\circ} \mathrm{C}$ selama 3 hari. Susut pengeringan sebesar $6,66 \%(b / b)$.

Penyiapan ekstrak etanol buah pare. Satu kilogram serbuk buah pare kering dimaserasi dengan 2,5 liter etanol 70\% selama 24 jam. Rendemen ekstrak yang diperoleh 7,4 \%(b/b).

Penyiapan hewan uji. Hewan uji yang digunakan adalah tikus galur Wistar umur 8 minggu dengan $\mathrm{BB} \pm 150$ gram. Dipelihara pada kandang individual dengan kondisi standar. Diberi makan dan minum ad libitum.

Induksi DM. DM pada tikus diinduksi dengan aloksan dosis $150 \mathrm{mg} / \mathrm{kg}$ BB dalam larutan saline 0,15 M secara intraperitoneal (Tripathi \& Chandra, 2009). Sampel darah untuk mengukur kadar glukosa setelah makan diambil melalui pembuluh okular pada mata. Kadar glukosa darah diukur pada hari yang berbeda menggunakan metode GOD-PAP. Setelah 4 hari tikus dipastikan DM dengan kadar glukosa > $230 \mathrm{mg} / \mathrm{dL}$ dan digunakan untuk perlakuan selanjutnya.

Perlakuan. Tikus dibagi menjadi 5 kelompok masing masing terdiri dari 6 ekor tikus.

\begin{tabular}{cl}
\hline $\begin{array}{c}\text { Kelompok } \\
\text { hewan uji }\end{array}$ & \multicolumn{1}{c}{ Perlakuan } \\
\hline I & Normal + CMC 1\% \\
II & DM + CMC 1\% \\
III & DM + glibenklamid $0,1 \mathrm{mg} / \mathrm{kg} \mathrm{BB}$ \\
IV & DM + perlakuan ekstrak dosis $100 \mathrm{mg} / \mathrm{kg} \mathrm{bb}$ \\
V & DM + perlakuan ekstrak dosis $200 \mathrm{mg} / \mathrm{kg} \mathrm{bb}$ \\
\hline
\end{tabular}

Berat badan diukur pada hari pertama tikus dipastikan DM, kemudian setiap 7 hari selama 30 hari perlakuan. Ekstrak diberikan secara oral satu kali sehari selama 30 hari. Pada masa akhir perlakuan tikus dikorbankan, hati dan pankreas disolasi untuk pengkuran kadar enzim antioksidan dan histopatologi jaringan pankreas.

Bahan. Aloksan, GOD-PAP reagen kit, buffer posfat, PMSF, EDTA, pereaksi untuk uji MDA dengan metode TBARS.

Preparasi supernatan. Hati dibersihkan kemudian dihomogenkan dalam buffer posfat 50 $\mathrm{mM}(\mathrm{pH} 7,4)$ yang mengandung inhibitor protease, 0,2 $\mu \mathrm{M}$ PMSF dan $1 \mathrm{mM}$ EDTA pada suhu $4{ }^{\circ} \mathrm{C}$ selama 30 detik ( $2 \neg 15$ detik dengan 15 detik interval pendinginan). Homogenat disaring dan filtrate disentrifuse pada $1088 \mathrm{~g}$ (pada $\mathrm{r}_{\max } 108 \mathrm{~mm}$ ) selama 5 menit dalam 
kondisi dingin. Supernatan yang dihasilkan digunakan untuk pengukuran kadar peroksidasi lipid.

Pengukuran kadar MDA. Pengukuran kadar MDA mengikuti Singh et al. (2002). Sebanyak $0,5 \mathrm{ml}$ supernatan hati ditambah $2,0 \mathrm{ml} \mathrm{HCl}$ dingin $(0,25 \mathrm{~N})$ yang mengandung $15 \%$ TCA, $0,38 \%$ TBA dan $0,5 \%$ BHT. Campuran dipanaskan $80^{\circ} \mathrm{C}$ selama satu jam. Setelah dingin, campuran disentrifuse pada $3500 \mathrm{rpm}$ selama 10 menit. Absorbansi supernatan diukur pada $532 \mathrm{~nm}$. Sebagai larutan standar digunakan tetratoksipropana (TEP).

Uji histopatologi. Jaringan pankreas difiksasi dalam larutan Bouin kemudian diembaded dalam parafin, kemudian dipotong dengan mikrotom dan dibuat slide. Slide diwarnai dengan hematoxaline dan Eosin. Struktur sel islet dilihat pada mikroskop, dengan inti sel dan pembuluh darah kapiler.

Analisis statistik. Data yang diperoleh dianalisis dengan One way anova dilanjutkan dengan uji post hoc dengan taraf kepercayaan 95\%. Uji korelasi menggunakan pearson colleration dengan taraf kepercayaan $95 \%$.

\section{HASIL PENELITIAN}

Efek ekstrak etanol pada berat badan (BB) ditunjukkan pada Tabel 1 dan kadar glukosa darah (Tabel 2)

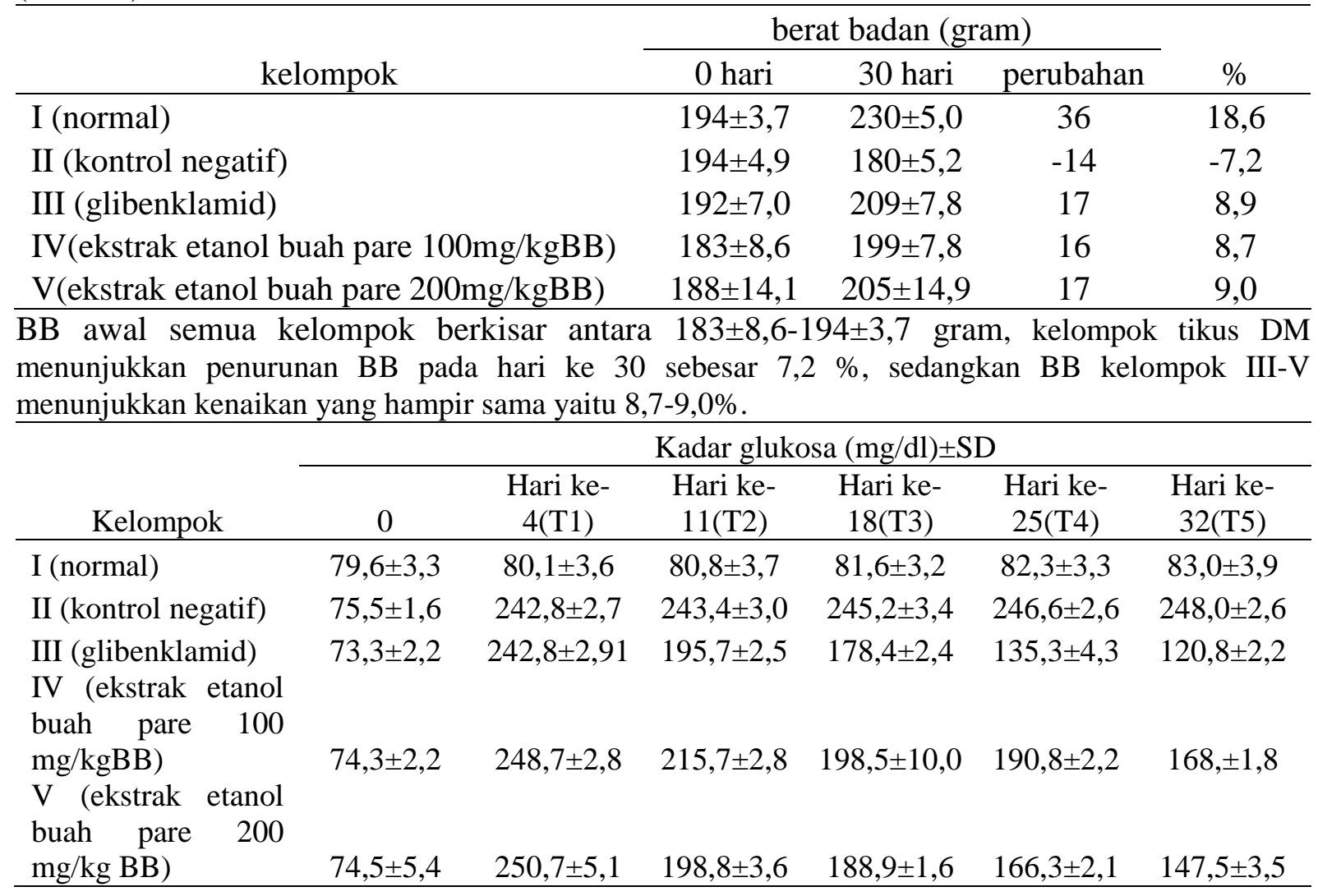

Kadar glukosa awal semua kelompok sama yaitu 73,3 $\pm 2,2 \mathrm{mg} / \mathrm{dL}-79,6 \pm 3,3 \mathrm{mg} / \mathrm{dL}$, setelah 4 hari injeksi aloksan $150 \mathrm{mg} / \mathrm{kg} \mathrm{BB}$, meningkatkan kadar glukosa pada kelompok II$\mathrm{V}$ mulai dari $242,8 \pm 2,7 \mathrm{mg} / \mathrm{dL}-250,7 \pm 5,1 \mathrm{mg} / \mathrm{dL}$. Kadar glukosa ini menetap pada kelompok kontrol DM sampai akhir masa perlakuan yaitu 248,0 $22,6 \mathrm{mg} / \mathrm{dL}$, sedangkan kelompok glibenklamid, ekstrak etanol dosis $100 \mathrm{mg} / \mathrm{kg}$ BB dan $200 \mathrm{mg} / \mathrm{kg}$ BB menurunkan kadar glukosa signifikan dibanding tikus DM.

Kadar MDA pada hati (Tabel 3). 


\begin{tabular}{lc}
\hline \multicolumn{1}{c}{ Kelompok } & MDA (nmol/mg) \\
\hline I (normal) & 4,05 \\
II (kontrol negatif) & 14,8 \\
III (glibenklamid) & 12,22 \\
IV (ekstrak etanol buah pare 100 mg/kg BB) & 7,77 \\
V (ekstrak etanol buah pare 200 mg/kg BB) & 3,32 \\
\hline
\end{tabular}

Kadar MDA pada homogenat hati meningkat signifikan $(p<0,05)$ pada tikus DM dibandingkan dengan tikus normal. Pemberian ekstrak etanol buah pare baik dosis $100 \mathrm{mg} / \mathrm{kg}$ BB maupun 200 mg/kg BB mampu menurunkan kadar MDA.

\section{Hasil histopatologi.}

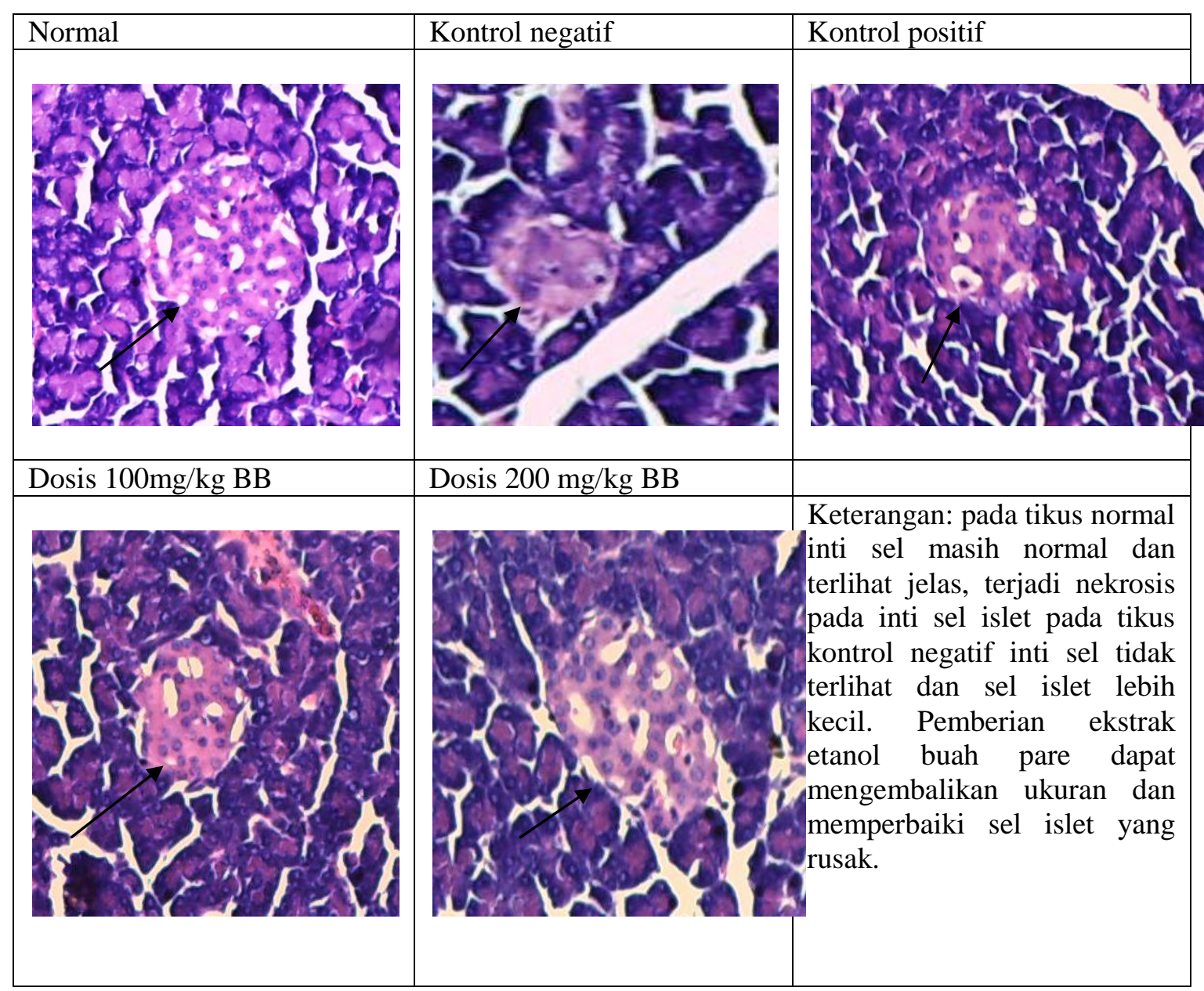

\section{PEMBAHASAN}

Berat badan merupakan salah satu indikator yang digunakan untuk memastikan tingkat penyerapan glukosa pada semua kelompok perlakuan. Pada kelompok normal, BB naik dari awal sampai minggu ke empat, karena kondisi hewan uji sehat, asupan makanan mencukupi dan penyerapan glukosa serta nutrisi lainnya masih normal. 
Pada kelompok kontrol negatif terjadi penurunan BB setelah induksi dengan aloksan intraperitoneal. Hasil ini menandakan bahwa induksi DM dengan aloksan dosis $150 \mathrm{mg} / \mathrm{kg}$ BB berhasil merusak sel beta pankreas yang mensekresikan insulin (Corrado et al., 2013). Defisiensi insulin menyebabkan transport glukosa ke dalam sel jaringan periperal berkurang. Kekurangan glukosa ini menyebabkan sel akan memetabolisme cadangan glikogen melalui glikolisis, meningkatnya katabolisme protein dimana asam amino yang dihasilkan digunakan sebagai substrat untuk glukoneogenesis dalam hati sehingga terjadi penurunan BB (Bannet \& Brown, 2008). Pada kelompok kontrol negatif terjadi penurunan BB dari 194 $\pm 4,9$ sampai $180 \pm 5,2$ dengan persentase penurunan sebesar 7,2 \% pada akhir minggu ke empat.

Kelompok kontrol positif menunjukkan kenaikan BB setiap minggu. Peningkatan BB ini dapat dikaitkan dengan jumlah insulin yang dilepaskan dari sel beta meningkat karena pemberian glibenklamid, Peningkatan insulin akan meningkatkan transport glukosa ke dalam sel sampai ke jaringan periperal dan mengarah pada pemanfaatan nutrisi penting lain, penyerapan asam amino dan komponen makromolekul lainnya (Kumar et al. 2013).

Persen peningkatan BB kelompok dosis ekstrak $200 \mathrm{mg}$ lebih tinggi dibandingkan kontrol positif yaitu sebesar 9\%. karena ekstrak etanol buah pare selain memiliki aktivitas insulinomimetik juga dapat menginduksi berbagai enzim metabolik yang bertanggung jawab terhadap pengambilan nutrien dan metabolisme makromolekul penting lainnya (Singh et al. 1989).

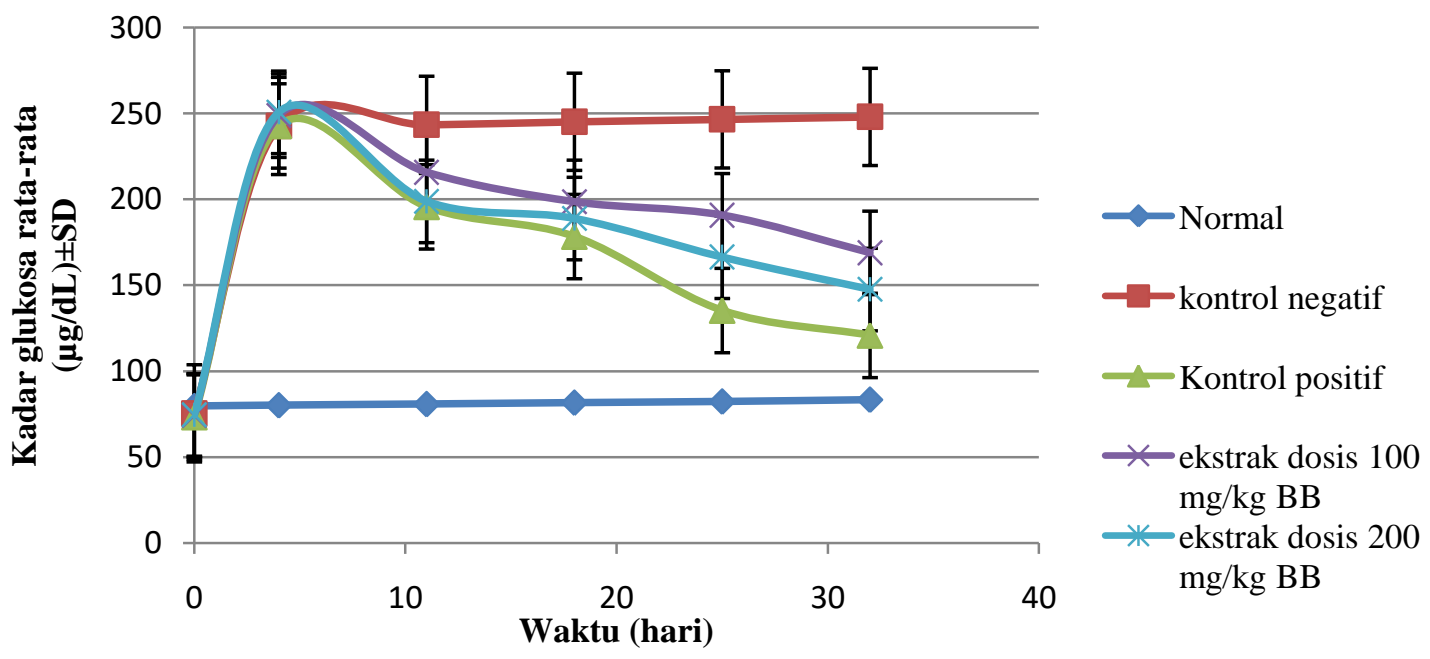

Dari grafik diatas dapat dilihat kadar glukosa darah tikus berubah pada setiap kelompok. Kelompok kontrol negatif menunjukkan kadar glukosa yang tetap tinggi sampai minggu ke empat, ini menandakan bahwa induksi berhasil membuat tikus menjadi DM. Kelompok kontrol positif dan ekstrak etanol buah pare menunjukkan terjadinya penurunan kadar glukosa. Dilihat dari Onset, glibenklamid segera menurunkan kadar glukosa pada minggu pertama (hari ke-4 sampai hari ke-7) dan terus turun mendekati nilai normal, berbeda dengan dosis $200 \mathrm{mg}$ ekstrak etanol buah pare pada minggu pertama penurunannya besar, tetapi masuk minggu ke dua (hari ke 11 samapi hari ke 18) terlihat penurunan semakin lambat. Dari data yang diperoleh, sebagai obat tradisional untuk DM, pare tidak berpotensi menyebabkan hipoglikemi karena efek penurunannya lambat dan merupakan karakteristik obat herbal dengan kandungan fitokimia yang banyak (ekstrak), berbeda dengan glibenklamid yang merupakan obat kimia sintesis murni, efek cepat dan efek samping bisa menyebabkan hipoglikemi (Modi, 2007).

Pada kelompok ekstrak dosis $100 \mathrm{mg}$ dan $200 \mathrm{mg}$ dapat menurunkan kadar glukosa darah signifikan $(\mathrm{p}<0,000)$ dibanding kelompok kontrol negatif, ini menunjukkan bahwa ekstrak etanol mempunyai aktivitas antihiperglikemi. Tetapi penurunan kadar glukosa juga signifikan dibandingkan dengan kelompok kontrol positif $(\mathrm{p}<0,05)$. Hal ini bisa dipengaruhi 
karena profil penurunan kadar glukosa ekstrak etanol terjadi cepat kemudian melambat, dari minggu ke minggu terjadi penurunan walaupun pada minggu ke empat tidak bisa mendekati kadar glukosa normal sehingga efektifitas antihiperglikemi tidak sebesar glibenklamid.

Aktivitas antihiperglikemi ekstrak etanol buah pare diduga melalui beberapa mekanisme yaitu: peningkatan sekresi insulin/ insulinomimetik, peningkatan jumlah GLUT-4 pada sel otot, meningkatkan uptake glukosa dalam hati, dan aktivitas antioksidan enzimatis baik secara langsung maupun tidak langsung juga bertanggung jawab terhadap aktivitas antihiperglikemi (Sathishekar \& Subramanian, 2005).Senyawa yang memiliki aktivitas antihiperglikemi adalah golongan steroid yaitu karantin, cucurbitane yang termasuk golongan triterpenoid, p-insulin suatu polipeptida yang mirip insulin dengan mekanisme insulinomimetik (Joseph B. \& Jini D., 2013)

Pada kelompok kontrol negatif, hiperglikemi kronis menginduksi terbentuknya ROS secara non enzimatis melalui autooksidasi glukosa menyebabkan terjadinya stres oksidatif . Stres oksidatif juga dapat dilihat dari peningkatan peroksidsi lipid, yaitu meningkatnya kadar MDA (Monroy \& Mejia, 2013). Kadar MDA sebagai tanda tingginya peroksidasi lipid, menghasilkan hidroperoksida yang dapat mengubah fluiditas membran sel dan merusak membran sel dengan mengubah aktivitas enzim dan reseptor yang terikat pada membran sehingga semakin besar kadar MDA maka diameter sel islet akan mengecil karena kerusakan pada membran sel (Erijuwa et al., 2010).

Mengecilnya diameter sel islet langerhans pada kelompok II dapat dipengaruhi tiga faktor, yang pertama yaitu rusaknya sel beta pankreas karena toksisitas aloksan sehingga sel mengalami nekrosis dan hiposelularitas (Corrado et al., 2013) kedua karena hiperglikemia kronis menyebabkan stres oksidatif yang tidak diimbangi dengan peningkatan enzim SOD dan GPx sebagai mekanisme pertahanan, ketiga karena produksi ROS yang berlebihan akan menekan pankreas deudenal homeobox factor -1 (PDx-1) yaitu gen pengkode trankripsi spesifik yang berfungsi menjaga fungsi normal sel islet sehingga menghambat proliferasi sel islet yang normal maupun yang rusak (Kanneto, 1999).

Pada kelompok ekstrak etanol buah pare terlihat diameter sel islet bertambah besar sesuai dengan kenaikan dosis. Hasil uji statistik dosis $200 \mathrm{mg} / \mathrm{kg} \mathrm{BB}$ ekstrak etanol buah pare meningkatkan susunan sel islet beta dengan diameter yang lebih besar dibanding dengan kontrol negatif $(\mathrm{p}<0,05)$. Sedangkan dosis $100 \mathrm{mg} / \mathrm{kg}$ BB pertambahan diameter sel islet berbeda tidak bermakna dengan kelompok II $(\mathrm{p}>0,05)$. Hasil ini sesuai dengan hasil penelitian Ayoub et al. (2013) histologi susunan sel islet meningkat dengan peningkatan dosis, dosis 200 $\mathrm{mg} / \mathrm{kg}$ BB memperbaiki sel islet mulai dari hari ke-15 sampai hari ke-45, terjadi peningkatan jumlah dan kekompakan sel islet, seluralitas tinggi dan jumlah insulin lebih besar dibanding dosis $100 \mathrm{mg} / \mathrm{kgBB}$.

\section{KESIMPULAN}

Ekstrak etanol buah pare memmpunyai aktivitas antihiperglikemi dan dapat menurunkan kadar MDA pada tikus DM yang diinduksi aloksan.

\section{DAFTAR PUSTAKA}

Ayoub M et al., 2013, Evaluation of hypoglycemic effect of Momordica charantia L. extract in distilled water in Streptozotocin-Diabetic rats, Braz J Vet Pathol. 6(2):56 - 64.

Corrado, 2013, Optimization and characterization of a bioartificial pancreas, Journal of undergraduated reasearch, $14: 3$

Droge W., 2002, Free Radicals in the Physiological Control of Cell Function, Physiological Reviews, 82: 47-95. 
Erejuwa O et al., 2010, Antioxidant protective effect of Glibenclamide and Metformin in combination with honey in pancreas of Streptozotocin induced Diabetic rats, Int. J. Mol. Sci. 11:2056-2066.

Gomathi D., Ravikumar G., Kalaiselvi M., Devaki K., Uma C., 2013, Efficacy of Evolvulus alsinoides L. on insulin and antioxidants activity in pancreas of streptozotocin induced diabetic rats, Journal of Diabetes \& Metabolic Disorders, 12:39.

Joseph B., Jini D., 2013, Antidiabetic effects of Momordica charantia L. And its medicinal potency, Asian pacific journal of tropical disease, 3(2): 93-102.

Kaneto H., 1999, Beneficial effects of antioxidants in diabetes, Diabetes. 2398-2405.

Kanter M., Coskun O., Korkmaz A., Oter S., 2004, Effects of Nigella sativa on oxidative stress and-cell damage in Streptozotocin-induced diabetic rats. The anatomical record. part A: 685-691.

Kumar SD., Sharathnath., Yogeswaran, 2010, A medicinal potency of Momordica charantia L. J. Pharm. Sci. Rev. Res. 18: 95-100.

Kumar V et al., 2013, Enhanced glycemic control, pancreas protective, antioxidant and hepatoprotective effects by umbelliferon- $\alpha$-D-glucopyranosyl-(2 glucopyranoside in streptozotocin induced diabetic rats, Springer Plus, 2:639.

Lee-Huang, 1995, Anti-HIV and anti-tumor activities of recombinant MAP30 from bitter melon, Gene, 61:151-156.

Modi P., 2007, Diabetes beyond insulin: review of new drugs for treatment of DM. Current drug discovery technologies, 4: 39-47.

Moniruzzaman M et al., 2012, In Vitro Antioxidant Effects of Aloe barbadensis Miller extracts and the potential role of these extracts as antidiabetic and antilipidemic agents on streptozotocin-induced type 2, journal molecules, 17. 12851-12867.

Monroy ML., Mejia CF., 2013, Oxidative stress in Diabetes Mellitus and the role of vitamins with antioxidant actions, Mexico Ntech, 9: 210-215).

Omoregbe R., Ikuebe, O., \& Ihimir, I., 1996, Antimicrobial activity of some medicinal plants extracts on Escherichia coli, Salmonella paratyphiand Shigella dysenteriaei, Afr. J. Med. Sc., 25:373-375.

Ravi K., Balasubramanian R., Sorimuthu S., 2004, Protective Effect of Eugenia jambolana seed Kernel on tissue, Biol. Pharm. Bull. 27(8): 1212-1217

Robertson P. R., 2004, Chronic oxidative stress as a central mechanism for glucose toxicity in pancreatic islet beta cells in diabetes, The Journal of Biological Chemistry. Vol. 279 (41):42351-42354.

Sathishsekar D., Subramanian S., 2005, Antioxidant properties of Momordica Charantia (bitter gourd) seeds on Streptozotocin induced diabetic rats, Asia Pac. J. Clin. Nutr., 14 (2):153-158 153.

Setiawan B., Suharsono E., 2005, Oxidative Stress and The Roles of Antioxidant in Diabetes Mellitus, Majalah Kedokteran Indonesia, Feb 55(2): 86-90.

Senanayake et al., 2004, The effects of bitter melon (Momordica charantia) on serum and liver triglyceride levels in rats, J. Ethnopharmacol., 91:257-262.

Wu S., Ng L., 2007, Antioxidant and free radical scavenging activities of wild bitter melon (Momordica charantia Linn. var. abbreviata Ser.) in Taiwan, LWT, 41:323-330. 
